Василькова Н.В.

канд. екон. наук, доиент

Київський національний економічний університет імені Вадима Гетьмана

\title{
КЛЮЧОВІ ФАКТОРИ УСПІХУ УНІВЕРСИТЕТІВ НА ГЛОБАЛЬНОМУ РИНКУ ОСВІТНІХ ПОСЛУГ
}

\section{КЛЮЧЕВЫЕ ФАКТОРЫ УСПЕХА УНИВЕРСИТЕТОВ НА ГЛОБАЛЬНОМ РЫНКЕ ОБРАЗОВАТЕЛЬНЫХ УСЛУГ}

\section{KEY SUCCESS FACTORS OF UNIVERSITIES IN THE GLOBAL EDUCATIONAL SERVICES MARKET}

У статті проаналізовано ключові чинники успіху в глобальній конкуренції на ринку освітніх послуг $i$ ринку знань, розглянуто основні відмінні риси університетів, щзо належать до групи найсильніших у світі, які визначають як "університети світового класу”. Посилення конкуренції у сфері вищої освіти, переведення ї̈ на глобальний рівень вимагають від університетів в різних краӥнах все більше впроваджувати в свою діяльність принципи ринковоорієнтованого управління, постійно вдосконалювати свою діяльність за всіма ї̈ напрямами. Вивчення досвіду лідерів галузі, аналіз їхніх сильних сторін, ідентифікування ключових факторів успіху на ринку, ознайомлення з крамими практиками, методами та інструментами є важливими напрямами маркетингових досліджень та конкурентного аналізу для будь-якої організації в умовах висококонкурентного ринку, яким сьогодні стає і ринок освітніх послуг. Також у статті розглянуто інші важливі для підвищення глобальної конкурентоспроможності вищого навчального закладу чинники.

Ключові слова: освітній маркетинг, ринок освітніх послуг, маркетингова орієнтація вищого навчального закладу, конкурентоспроможність університету, ключові фактори успіху на глобальному ринку освітніх послуг.

В статье проанализированы ключевые факторы успеха в глобальной конкуренции на рынке образовательных услуг и рынке знаний, рассмотрены основные отличительные черты университетов, принадлежаших к группе сильнейших в мире, которые определяют как "университеть мирового класса". Усиление конкуренции в сфере высшего образования, перевода ее на глобальныии уровень требуют от университетов в различных странах все больше внедрять в свою деятельность принщипы рыночноориентированного управления, постоянно совершенствовать свою деятельность по всем ее направлениям. Изучение опыта лидеров отрасли, анализ их сильных сторон, идентификация ключевых факторов успеха на рынке, ознакомление с лучшими практиками, методами $и$ инструментами являются важными направлениями маркетинговых исследований $u$ конкурентного анализа для любой организации в условиях высококонкурентного рынка, которым сегодня становится и рынок образовательных услуг. Также в статье рассмотрены другие важные для повышения глобальной конкурентоспособности высшего учебного заведения факторы. 
Ключевые слова: образовательный маркетинг, рынок образовательных услуг, маркетинговая ориентация высшего учебного заведения, конкурентоспособность университета, ключевые факторы успеха на глобальном рынке образовательных услуг.

The article analyses the key success factors in the global competition in educational services market and knowledge market, considers main features of universities in the group of the strongest in the world, which are defined as "world class universities". Increased competition in higher education, which is becoming more global, demands from universities in different countries to increasingly embed the principles of market-oriented management in their activities, continuously improve their activities in all areas. Studying the experience of industry leaders, analysis of their strengths, identifying the key success factors in the market, getting acquainted with the best practices, methods and tools are important areas of market research and competitive analysis for any organization in a highly competitive market, which also the market of educational services is becoming today. The article also highlights other factors which are important to enhance the global competitiveness of a higher education institution.

Keywords: higher education marketing, educational services market, marketing orientation of the higher education institution, university's competitiveness, key success factors in the global educational services market.

Вступ. Загострення конкуренції на ринку освітніх послуг, в тому числі i через процеси глобалізації, вимагають сьогодні від університетів впровадження принципів і підходів ринкової орієнтації в свою діяльність та використання всього спектру маркетингових інструментів. Університети сьогодні вже не є лише “спокійним місцем для викладання та наукової роботи, ...як у минулі століття. Це великий, складний, вимогливий, конкурентоспроможний бізнес, що вимагає великих поточних інвестицій» [7, c. 5]. 3 початку XXI ст. національні системи вищої освіти різних країн суттєво реформуються 3 метою посилення їх міжнародної конкурентоспроможності. Наслідком посилення конкуренції і переведення iї на глобальний рівень $\epsilon$ i необхідність для університетів запроваджувати окремі принципи ринковоорієнтованого управління, розуміння i ефективне опанування технологіями та інструментами освітнього маркетингу.

Проблемам освітнього маркетингу присвячені наукові праці українських (Т.С. Оболенська, І.Л. Решетнікова, М.Я. Матвіїв, В.С. Вознюк, З.В. Рябова, І.В. Мороз, В.В. Сиченко, Л.О. Волокітіна, А.М. Лялюк та ін.) та зарубіжних (Ф.Котлер, К.Фокс, А.В.Астін, Г.Свенссон, Г. Вуд, В. Бехлер, І.С.Вудворд, В.М.Х.Борден, Р.Акерман, А.П. Панкрухін, С.А. Іващенко, О.Ю. Маркова, І.С. Петрушина та багато інших) вчених. Значний внесок у вивчення питань конкурентоспроможності вищих навчальних закладів на глобальному ринку освітніх послуг і ринку знань зробили такі дослідники як Дж.Салмі, Ф. Альтбах, Дж. Балан та інші.

Для України дослідження проблем конкурентоспроможності в сфері вищої освіти, факторів, що впливають на успіх та на конкурентні позиції університетів стають все більш актуальними, що викликано як зростанням 
конкуренції на національному рівні, так і прагненням українських ВНЗ до більшої інтеграції у глобальний ринок освітніх послуг і ринок знань.

Постановка завдання. Метою статті є узагальнення поглядів науковців на ключові чинники успіху в глобальній конкуренції в сфері вищої освіти, розуміння яких є основою для розробки ефективної маркетингової стратегії вищого навчального закладу, який прагне міжнародного визнання.

Методологія. Методологічною основою даного дослідження стали загальнонауковий метод теоретичного узагальнення, метод порівняльного аналізу, принципи системного аналізу, методи маркетингових досліджень.

Результати дослідження. Маркетингова орієнтація вищого навчального закладу передбачає, що основним його завданням $\epsilon$ «визначення потреб і бажань цільових ринків та задоволення їх завдяки розробці, комунікації, ціноутворенню і постачанню споживачам відповідних програм і послуг» $[1, \mathrm{c.}$ 8]. Не менш важливим для формування конкурентоспроможної пропозиції $\epsilon$ дослідження конкурентів, вивчення тенденцій в сфері вищої освіти та розуміння ключових факторів успіху на ринку освітніх послуг.

Аналіз результатів останніх досліджень, присвячених питанням глобальної конкурентоспроможності університетів, дозволяє виділити визначальні характеристики університетів-світових лідерів - таких, що входять до числа топ-100 або топ-200 в провідних міжнародних рейтингах i яких прийнято називати “університети світового класу”. Університетам цієї групи притаманні такі ознаки:

- якість досліджень та сильне міжнародне партнерство i співробітництво;

- можливість наймати найкращий професорсько-викладацький, науково-дослідницький, управлінський, адміністративний персонал, ведучи пошук таких професіоналів не лише в межах своєї країни, а на глобальному ринку праці,

- створення умов для можливості співпраці своїх дослідників 3 кращими фахівцями у відповідній галузі науки, незалежно від того, в якій країні вони знаходяться;

- компетенції $з$ широкого спектру галузей науки і дисциплін (суспільні, гуманітарні науки, інженерні науки, математика, природничі, медичні науки тощо);

- потужне керівництво з чіткими місією та баченням для організації;

- автономія: організаційна, фінансова, академічна та кадрова;

- висока якість навчання та спроможність залучати найкращих студентів (у тому числі для магістерського та докторського рівнів освіти) не лише на національному, а й на міжнародному рівнях (відсоток іноземних студентів у провідних університетах світу з кожним роком зростає); 
- змішане, диверсифіковане фінансування, що означає відсутність надмірної залежності лише від одного джерела фінансування.

Всесвітньо відомий експерт у сфері вищої освіти Джаміл Салмі [9] визначає ключові фактори успіху університетів світового класу за трьома основними категоріями, а саме:

- концентрація таланту (інтернаціоналізація),

- потужне фінансування,

- ефективне управління.

Розглянемо ці фактори докладніше.

\section{1. Інтернаціоналізація: концентрація таланту}

Поняття "інтернаціоналізація" або “концентрація таланту” описує перший набір визначальних характеристик університетів світового класу. Концентрація таланту стосується людських ресурсів університету - його студентів та персоналу. В обох випадках університет світового класу спроможний на конкурсній основі залучати найкращих вчених та студентів. Оскільки вважається, що таланти рівномірно розподілені по всьому світу, характеристика "концентрація таланту" автоматично означає високий ступінь іноземних студентів і викладачів в таких університетах. Визнано, що інституції, які практикують “ендогамію”, тобто які надають перевагу студентам і дослідникам 3 власної країни, не спроможні досягти верхівки міжнародних рейтингів. Виходячи 3 цього, різні дослідники погоджуються, що “концентрація таланту” в даному контексті ідентична терміну “інтернаціоналізації”. Дж. Сандлак та Ліу Ніан Кай [8, с. 14] дійшли висновку, що іноземні студенти, викладачі та інші прояви інтернаціоналізації стали виміром конкурентоспроможності у сучасному освітньому середовищі.

Право університету відбирати для себе студентів має ключову значущість, оскільки дозволяє набирати найкращих. При цьому конкуренція між талантами постійно зростає, стимульована різними видами стипендій, грантів, податкових пільг, потужним фінансуванням проектів та іншими вигодами і перевагами. Провідні університети, реалізуючи своє право вільно вибрати для себе студентів, організовують прийом на навчання на умовах жорсткої конкуренції, у спосіб, що дозволяє підібрати академічно найвидатніших студентів з національного і міжнародного середовищ. Свобода університету відбирати студентів, таким чином, $\epsilon$ однією 3 передумов лідерства університету. Конкуренція за найкращі таланти практично завжди включає стимули, такі як надання стипендій (для найкращих студентів або для студентів, що потребують фінансової підтримки) та забезпечення найкращих умов навчання (високоякісних гуртожитків, інших послуг для студентів, спортивних споруд тощо) [3].

Для досягнення рівня світового класу важливою $\epsilon$ можливість університету вільно приймати на роботу і звільняти персонал. При цьому 
провідні університети оголошують конкурси на заміщення вакантних посад викладачів, дослідників, співробітників, управлінців на міжнародному рівні та набирають персонал, не обмежуючись національними кордонами, і також автономно вирішують питання щодо заробітної плати, інших типів винагород, умов роботи. За академічний персонал з видатними досягненнями конкурують провідні дослідницькі університети, наслідком чого $є$ постійне і надзвичайне зростання зарплат для таких фахівців [9, с. 25]. Більшість дослідників вважають, що системи освіти, в яких професори мають статус цивільного службовця (надає такі переваги, як і статус державного службовця) з чітко встановленими межами зарплати, не $\epsilon$, як правило, ефективним рішенням. Такі системи не стимулюють видатні досягнення i тим самим у довгостроковій перспективі підривають амбіції найкращих фахівців. Однак є і виключення: Швейцарії вдалось підтримувати статус окремих своїх університетів як університетів світового класу, незважаючи на використання моделі цивільних службовців. Також у Китаї така модель не заперечує загальному прогресу китайських університетів. Це ще раз підкреслює те, що в основі університету світового класу лежить не один, а комбінація факторів.

Створення умов для залучення найкращих викладачів i дослідників означає надання їм можливості працювати однією з глобально поширених мов, в основному англійською. Університети в не англомовних країнах сьогодні, щоб залучити провідних дослідників, мають забезпечити середовище для викладання i досліджень англійською мовою. Це також важливий фактор і для залучення кращих іноземних студентів. У результаті, кращі університети по всьому світу все більше стають інституціями, що значною мірою функціонують англійською мовою.

2. Фінансування

Достатність фінансових ресурсів є другою важливою характеристикою університетів-лідерів в глобальному освітньому просторі. Для досягнення вищим навчальним закладом рівня дослідницького університету світового класу необхідні величезні витрати, що вимагає потужного фінансування. Хоча в кожному випадку є свої особливості, більшість провідних університетів не покладаються лише на одне джерело фінансування. Як правило, вони:

1) отримують базове фінансування 3 державного бюджету - для поточних витрат і досліджень;

2) виграють фінансування на проведення досліджень на основі договорів $з$ державними і приватними організаціями, беручи участь у тендерах на умовах конкуренції;

3) користуються власними фондами цільового капіталу “ендавментами” (у світовій практиці “ендавмент” - цільовий фонд, призначений для використання в некомерційних цілях, як правило, для фінансування організацій освіти, медицини, культури. Джерела формування 
фондів ендавменту різні. Наприклад, гарвардський ендавмент щорічно поповнюється в основному за рахунок пожертвувань студентів університету).

4) отримують власні доходи від плати студентами за навчання.

Серед дослідників немає єдності у поглядах щодо найбільш оптимальної комбінації джерел фінансування, а також на питання стосовно того, які 3 закладів вищої освіти - приватні або державні - мають більше можливостей для того, щоб досягти статусу університетів світового класу. Однак, всі дослідники погоджуються з тим, що значні державні інвестиції є для цього неодмінною умовою у майже всіх випадках, і дотримуються думки, що кількість університетів світового класу, які фінансуються виключно 3 приватних джерел (для одержання прибутку), і в майбутньому, скоріше за все, залишиться обмеженою. Згідно результатів дослідження Дж. Салмі, навіть в США приватні некомерційні університети, які часто є кращими за державні, також частково фінансуються державою (переважно, через отримання університетами на конкурсній основі контрактів на проведення досліджень від організацій, що фінансуються державою), і державні кошти складають значну частку у загальному бюджеті таких університетів. Інший відомий дослідник Ф. Альтбах проаналізував дослідницькі університети в різних країнах світу і дійшов висновку, що “дослідницькі університети, з незначним виключенням, є суспільними інституціями, що отримують державне фінансування. Лише в кількох країнах (таких як Чилі, Японія, США) існують приватні дослідницькі університети" [2]. Він також вважає, що i в майбутньому приватні дослідницькі університети навряд чи стануть масовим явищем і залишаться, скоріше, виключенням. Більшість приватних вищих навчальних закладів у світі є прибутковими інституціями, орієнтованими лише на викладання, i фінансуються вони майже виключно за рахунок оплати навчання студентами. Ф.Альтбах наголошує, що дуже високі витрати, яких потребує проведення досліджень, особливо фундаментальних, не дають можливості у коротко- $\mathrm{i}$ середньостроковій перспективі повернути інвестиції, що обмежує можливості приватних комерційних університетів у сфері провідних наукових досліджень. Дослідження даного питання також свідчать, що університети, які значну частку доходу отримують через конкурентні гранти (державні або приватні), мають більше шансів досягти статусу світового класу, однак, для того, щоб університет взагалі потрапив “у вищу лігу”, необхідні значні обсяги прямого державного фінансування.

Сильною стратегічною перевагою американських університетів, лідерів світового освітнього простору, $\epsilon$ потужні фонди цільового капіталу ендавменти (в окремих університетах їх річний дохід на одного студента становить приблизно 40 тис. дол. США). Ендавмент суттєво зміцнює університет, робить його менш залежним від зміни державних пріоритетів та дозволяє університету переслідувати власні довгострокові стратегічні цілі. 
Університети США накопичували такі фонди протягом тривалого періоду часу, і на кінець 2015 року ринкова вартість ендавменту Університету Гарвард становила більше 37,6 млрд. дол., Університету Йєль - 25,6 млрд. дол., Університету Прінстон - 23,5 млрд. дол. США [5]. За межами США такі фонди пожертвувань є рідкістю. У Великій Британії деякі університети мають ендавмент-фонди, але їхні обсяги значно менші за американські. Для поширення практики застосування такого інструменту фінансування університетів необхідна державна підтримка - наприклад, у формі податкових стимулів.

Плата за навчання, яка є четвертою серед названих вище складових доходу університетів, характерна для більшості провідних університетів світу. В США плата за навчання є стандартною рисою університетів, і все частіше вона стає нормою в інших країнах світу. Для того щоб плата за навчання не стала перешкодою на шляху досягнення мети залучати найбільш кваліфікованих студентів 3 усього світу, вона, як правило, врівноважена системою пільгових кредитів та стипендій для кращих студентів або таких, що потребують матеріальної допомоги. В деяких країнах плата за навчання відсутня (наприклад, країни Північної Європи, Австрія). Німеччина, яка ввела близько 10 років назад невисоку плату за навчання, в 2014 році знову іiі скасувала (в 2015 році - також для іноземних студентів). Відсутність доходів від плати за навчання університетам дозволяє компенсувати державна підтримка, яка в таких країнах є досить високою.

Університети, які є лідерами на глобальному ринку, або такі, що прагнуть ними стати, як правило, ставлять перед собою цілі і визначають відповідні показники в сфері наукових досліджень - такі як кількісне збільшення публікацій професорсько-викладацького складу у відомих міжнародних рецензованих фахівцями наукових журналах, включення індексів цитування робіт професорсько-викладацького складу в стандартні показники або досягнення певного мінімального рангу у визнаних міжнародних рейтингах університетів (ARWU, THE, QS). В таких установах також надзвичайно високий рівень міжнародного співробітництва та партнерства, який вони підтримують, адже передові у глобальному масштабі дослідження є сьогодні міжнародними. Найбільш часто використовуваним засобом вимірювання результатів дослідження $\epsilon$ їхнє цитування у міжнародних журналах. За таких умов інвестиції в зростання міжнародного партнерства та співробітництво в сфері досліджень має життєво важливе значення для будь-якого університету, що прагне досягти рівня світового класу. Ще одним результатом міжнародного співробітництва в сфері наукових досліджень $\epsilon$ сприяння значному зростанню мобільності студентів, професорсько-викладацького та адміністративного персоналу, що веде до 
покращення міжнародного профілю університету та підвищення його ефективності.

Найважливішою умовою раціональності використання провідними університетами фінансових ресурсів $\epsilon$ забезпечення студентів та професорсько-викладацького й інших категорій персоналу найкращими серед можливих умовами для досліджень, викладання, навчання і роботи. Ці умови стосуються матеріальної винагороди співробітників, а також умов роботи та навчання, робочого i навчального середовищ. Передові лабораторії, інфраструктура та обладнання, сучасні бібліотеки та сучасні інформаційні технології грають тут провідну роль. Для студентів стандартними вимогами, як вже згадувалось, $є$ також високоякісна соціальна інфраструктура університету / університетського містечка.

\section{3. Управління університетом}

Ефективне управління $\epsilon$ третьою важливою характеристикою університетів світового класу. Питання управління університетом включає $\mathrm{i}$ питання відносного ступеня автономії, якої установа потребує, щоб досягти верхівки міжнародних рейтингів. Згідно результатів дослідження [6], що стосувалось моделей управління університетами, різні концептуальні моделі можуть бути описані однією 3 наступних характеристик: “колегіальна", "бюрократична", “політична", “організована анархія" або “професійна". Останні публікації додають до цього переліку також "підприємницький університет", “сервісний університет", “підприємство університет” та “корпоративний / управлінський університет”. Як свідчить практика, університети світового класу потребують високого ступеня автономії. Класично розрізняють зовнішній і внутрішній виміри автономії.

Зовнішній вимір автономії стосується відносин між урядом та університетом, а також відносного ступеня свободи університету від втручання ззовні (передусім, держави). Університети світового класу мають максимальну свободу, за винятком деяких основних передумов, як, наприклад, необхідність діяти в межах законів відповідної країни. Мінімальними умовами автономії, які сьогодні виконуються в майже всіх розвинених економіках, $\epsilon$, як вважають провідні дослідники в цій сфері Дж.Салмі та Ф.Альтбах, те, що університети повинні:

- бути самостійною юридичною особою,

- мати право укладати контракти,

- мати право володіти власними активами.

Очевидно, що умовою досягнення університетом рівня світового класу $є$ «академічна свобода». Ф. Альтбах [2, с. 11] розрізняє два типи академічної свободи: 
1) більш обмежена (iї визначають як «німецьку»), яка гарантує вільне здійснення викладання i наукових досліджень без будь-яких обмежень політичного, ідеологічного або релігійного характеру;

2) більш широка концепція академічної свободи, яка захищає свободу академічного персоналу висловлюватись з будь-яких питань, що становлять суспільний інтерес.

Для того, щоб університет досягнув рівня світового класу, необхідно, щоб у ньому існувала академічна свобода хоча б у іiі обмеженому варіанті. Зазвичай автономія університетів світового класу $є$ більшою, ніж цього вимагають базові умови. Такі університети, зокрема, можуть:

- вільно використовувати свої ресурси (кошти) - за самостійно визначеними напрямами і без обмежень,

- розробляти власні плани розвитку, роботи,

- самостійно визначити пріоритети своєї науково-дослідницької

- приймати рішення стосовно своїх навчальних планів і програм,

- відбирати для себе найкращих студентів на умовах конкуренції,

- вільно встановлювати плату за навчання,

- відбирати, приймати на роботу i звільняти співробітників i академічний персонал,

- вільно приймати рішення про винагороду професорсько-викладацького корпусу та інші вигоди.

Внутрішній вимір автономії відноситься до того, як університет організовує свою роботу. Незаперечним сьогодні $\epsilon$ той факт, що університети-світові лідери потребують дуже сильного керівництва. Дослідження цього питання для університетів світового класу свідчать про те, що:

1) посада президента університету (або ректора, віце-канцлера) повинна передбачати широкі повноваження;

2) керівництво високорезультативних університетів має розробити бачення, місію та план розвитку установи;

3) вище керівництво повинно мати можливість і здатність зацікавити весь академічний та інший персонал у досягненні загальних цілей і завдань на користь всього університету.

Однак, на думку багатьох дослідників, внутрішня автономія повинна мати певні обмеження у питаннях самоврядування - вона не може бути синонімом «повного самоврядування». Внутрішні керівні органи, що складаються виключно 3 членів університету, повинні бути доповнені керівними органами із залученням представників зовнішніх кіл (з приватного сектору або громадських установ). Так, самоврядування професорсько-викладацького персоналу (наприклад, у формі Академічного 
Сенату) доповнюється Університетськими Радами, які частково складаються 3 зовнішніх представників.

Інші фактори успіху університетів світового класу є більш “м'якими”, але також дуже важливими. Дж. Салмі визначає "культуру переваги (відмінності) i конкурентоспроможності" (culture of excellence and competitiveness), а також "культуру постійного самоаналізу та відкритості до змін" (culture of constant self-questioning and openness to change), яка важко піддається вимірюванню через кількісні показники.

Всі названі вище чинники успіху на ринку освітніх послуг впливають на результати діяльності і конкурентні позиції університетів. Однак, більш важливим є їхній взаємодоповнюючий і взаємопосилюючий характер - кожен фактор має максимальний ефект лише тоді, коли інші умови також виконуються. Так, наприклад, наявні в університеті значні фінансові ресурси не принесуть бажаних результатів, якщо відсутні ефективні структури управління. Результати досліджень доводять, що збільшення фінансових ресурсів має набагато сильніший вплив на результати університету, коли воно пов'язано 3 фінансовою автономію. За оцінками дослідників, фінансова автономія подвоює ефект додаткових коштів на результати університетських досліджень" [4].

Крім розглянутих вище ключових факторів успіху можна виділити інші важливі для підвищення конкурентоспроможності ВНЗ чинники, це:

Багатогранність. Приділяючи особливу увагу науковим дослідженням, провідні університети світу є також установами, що надають освітні послуги студентам, від рівня бакалавра і вище. Університети світового класу дуже рідко є вузько спеціалізованими установами i, як правило, вони охоплюють широкий спектр наукових галузей, що відкриває можливості для міждисциплінарної роботи (в сфері досліджень, викладання, консалтингу тощо) в межах університету. Додатковою перевагою $\epsilon$ те, що мультидисциплінарні університети зазвичай за розміром є більшими за спеціалізовані, а за існуючих систем рейтингування шанси для більших інституцій потрапити до рейтингу є вищими, ніж для малих.

- Пропозиція навчальних програм на другому і третьому рівнях вищої освіти. Більшість дослідників вважає, що університети світового класу мають набагато більш високу частку студентів на магістерському і докторському $(\mathrm{PhD})$ рівнях, ніж університети, що не належать до найкращих у світі. При цьому не лише кількість студентів на подальших (після бакалаврського) рівнях освіти грає роль, а й форма освіти та умови навчання. Так, деякі дослідники вбачають особливу важливість у створенні graduate schools - шкіл (інституціональних утворень, часто напівнезалежних від самого університету), які займаються подальшою освітою випускників-бакалаврів на магістерському і докторському $(\mathrm{PhD})$ рівнях. 
- Підприємництво. Деякі автори звертають увагу на підприємницьку орієнтацію університетів світового класу, їхній зв'язок 3 корпоративним світом та на питання комерціалізації у широкому сенсі. Однак, Ф.Альтбах, який підкреслює, що університети є, насамперед, установами “суспільного блага”, застерігає від занадто тісних зв'язків університетів і бізнесу, і має критичний погляд на угоди між університетами і приватними компаніями для виробництва специфічних дослідницьких продуктів або відкриття університетських лабораторій для корпорацій. В таких тенденціях він вбачає загрозу класичним академічним цінностям, що підриває автономію університетів і переміщує фокус уваги їх досліджень на інші напрямки. Інші дослідники також вважають, що пряма участь університетів на ринку небажана, але університети мають забезпечити права інтелектуальної власності на результати своїх досліджень і повинні отримувати фінансові вигоди від їх використання. Крім того, вони допускають непряму форму присутності університетів на ринку у вигляді компаній-паростків (spin-off companies), що знаходяться в їхній власності або у спільній власності 3 корпораціями.

Висновки. Конкурентоспроможність сучасних університетів значною мірою залежить від рівня їх ринкової орієнтації, визначення на основі результатів всебічних маркетингових досліджень стратегічних орієнтирів свого розвитку, розробки ефективної маркетингової стратегії і докладання зусиль до постійного вдосконалення своєї щоденної діяльності 3 метою максимального задоволення потреб цільових груп споживачів. При цьому важливим $\epsilon$ розуміння сучасного конкурентного середовища та тенденцій розвитку сфери вищої освіти. Дослідження свідчать, що основними факторами успіху університетів світового класу сьогодні є: концентрація таланту (інтернаціоналізація); потужне i диверсифіковане за джерелами фінансування; високоефективне управління. Іншими характерними рисами університетів світового класу визначають: багатогранність (такі установи одночасно є дослідницькими і навчальними; пропонують широкий спектр фахових напрямів і дисциплін; вони $є$ достатньо великими за розміром 3 огляду на кількість студентів і співробітників); в освітній діяльності такі університети концентрують зусилля на пропонуванні навчальних програм магістерського і докторського $(\mathrm{PhD})$ рівнів, при чому майже всі університети світового класу пропонують структуровані $\mathrm{PhD}$-програми у формі шкіл для випускників-бакалаврів (graduate schools); підприємницька орієнтація (хоча щодо цієї ознаки консенсусу серед дослідників немає, всі дослідники погоджуються 3 тим, що університети повинні отримувати прибуток від результатів своєї наукової роботи); участь у міжнародному науковому співробітництві та зв'язках зі своїми колегами за кордоном. Подальші дослідження в цій сфері можуть бути присвячені розробці шляхів підвищення 
міжнародної конкурентоспроможності системи вищої освіти України, а також формуванню і розвитку конкурентних переваг провідних ВНЗ країни з метою посилення їх міжнародної діяльності та міжнародного визнання.

\section{Лiтература:}

1. Котлер Ф., Фокс К. Стратегічний маркетинг для навчальних закладів. Пер. з англ. - К.: УАМ, Вид. Хімджест, 2011. - 580 с.

2. Altbach P., Balan, J. (eds.) World Class Worldwide: Transforming Research Universities in Asia and Latin America. Baltimore, MD: Johns Hopkins University Press 2007.

3. Kelo M. Support for international students in higher education. Practice and Principles. / ACA Papers on International Cooperation in Education. Bonn: Lemmens 2008.

4. Kerr C. The Uses of the University. Cambridge: Harvard University Press 2001.

5. Lorin J. Cash-Strapped Connecticut Wants to Tax Yale Endowments. / Режим доступу: http://www.bloomberg.com/news/articles/2016-03-23/yale-endowment-tax-proposal-eyed-by -cash-strapped-connecticut

6. Meek V.L., Davies D. Policy Dynamics in Higher Education and Research: Concepts and Observations. UNESCO Forum on Higher Education 2009.

7. On the Edge: Securing a Sustainable Future for Higher Education. / OECD Education Working Papers, No. 7, OECD Publishing 2007.

8. Sadlak J., Liu Nian Cai (eds.). The World-class University as Part of a New Higher Education Paradigm. Bucharest: CEPES 2009

9. Salmi J. The Challenge of Establishing World-Class Universities. Washington: World Bank 2009. 